This is an author produced version of a paper published in Regulatory peptides. This paper has been peer-reviewed but does not include the final publisher proof-corrections or journal pagination.

Citation for the published paper:

Salehi, Albert and Eliasson, Lena and Ma, Xiaosong and Rorsman, Patrik and Hakanson, Rolf and Lundquist, Ingmar.

"Secretory and electrophysiological characteristics of insulin cells from gastrectomized mice: Evidence for the existence of insulinotropic agents in the stomach"

Regulatory peptides, 2006, Issue: Nov 14. http://dx.doi.org/10.1016/j.regpep.2006.10.001

Access to the published version may require journal subscription. Published with permission from: Elsevier 


\title{
Secretory and electrophysiological characteristics of insulin cells from gastrectomized mice: Evidence for the existence of insulinotropic agents in the stomach
}

\author{
Albert Salehi ${ }^{1}$, Lena Eliasson ${ }^{1}$, Xiaosong $\mathrm{Ma}^{1}$, Patrik Rorsman ${ }^{1}$, Rolf \\ Håkanson $^{2}$ and Ingmar Lundquist ${ }^{1}$
}

Department of Experimental Medical Science, Division of Diabetes, Metabolism and Endocrinology ${ }^{1}$ and Division of Cellular and Molecular Pharmacology ${ }^{2}$, University of Lund, LUND; Sweden

Running title: Gastrectomy and insulin secretion

Key words: Insulin release, Gastrectomy, Exocytosis, cAMP

Proofs and correspondence:

Dr. Albert Salehi,

Department of Experimental Medical Science

Division of Diabetes, Metabolism and Endocrinology

University of Lund

BMC B11

S-221 84 Lund, Sweden

E-mail: S_Albert.Salehi@med.lu.se 


\section{Abstract}

Mice were subjected to gastrectomy (GX) or sham operation (controls). After 4-6 weeks the pancreatic islets were isolated and analysed for cAMP or incubated to study insulin secretion and cAMP accumulation in response to glucose or to the universal adenylate cyclase activator forskolin. Pancreatic islets from GX mice had higher cAMP content than islets from control mice, a difference that persisted after $1 \mathrm{~h}$ of incubation at a low glucose concentration $(4.0 \mathrm{mmol} / \mathrm{l})$. Addition of forskolin to the incubation medium (glucose $4 \mathrm{mmol} / \mathrm{l}$ ) induced much greater cAMP and insulin responses in islets from GX mice than in islet from control mice. The insulin response to high glucose $(16.7 \mathrm{mmol} / \mathrm{l})$, however, was much weaker in GX islets than in control islets. Similarly, there was a 2fold rise in the cAMP content in control islets but no rise in islets from GX mice following incubation with high glucose. Capacitance measurements conducted on isolated insulin cells from GX mice revealed a much lower exocytotic response to 500 msdepolarisation (from $-70 \mathrm{mV}$ to zero) than in control insulin cells. Addition of cAMP to the pipette solution enhanced the exocytotic response in insulin cells from control mice but not from GX mice. The depolarisation-triggered inward $\mathrm{Ca}^{2+}$ current in insulin cells from GX mice did not differ from that in control mice, and hence the reduced exocytotic response cannot be ascribed to a decreased $\mathrm{Ca}^{2+}$ influx. Continued depolarisation-evoked stimulation revealed that the exocytotic response of insulin cells from GX mice to a train of ten 500 ms-depolarisations was only modestly increased by cAMP, whereas cAMPstimulated exocytosis was prominent in control insulin cells. Thus, insulin cells from GX mice did not respond at first to depolarisation, not even after infusion of cAMP into the cell interior. Paradoxically, however, the forskolin-evoked rise in cAMP in GX islets was accompanied by an amplified insulin release. This observation contrasts with the finding that addition of cAMP to the cytosol during prolonged depolarisation only marginally increased exocytosis in insulin cells from GX mice. It seems that cAMP is capable of eliciting insulin release from insulin cells of GX mice, but only when cAMP is generated by a universal adenylate cyclase activator such as forskolin. The GX-evoked impairment of depolarisation-induced exocytosis and of glucose-stimulated insulin release may reflect the lack of a gastric factor that serves to maintain an appropriate insulin response to glucose by promoting the mobilization of cAMP from a sequestered glucose-sensitive compartment. 


\section{Introduction}

Insulin cells release insulin in response to a rise in blood glucose. The current view is that the uptake of glucose into the insulin cell results in an increased intracellular ATP concentration. The increase in ATP (at the cost of ADP) leads to closure of ATP-dependent $\mathrm{K}^{+}$-channels, depolarisation of the cell membrane and influx of $\mathrm{Ca}^{2+}$ through voltage-dependent $\mathrm{Ca}^{2+}$ channels. The consequent increase in intracellular $\mathrm{Ca}^{2+}$ in the vicinity of the $\mathrm{Ca}^{2+}$-channels initiates granule exocytosis and insulin release [1]. Several events in the process of glucoseinduced stimulus- secretion coupling are influenced by cAMP. Hence, formation of cAMP from ATP leads to activation of protein kinase A (PKA) [2-4] and stimulates $\mathrm{Ca}^{2+}$ release through a PKA-dependent mechanism [5, 6]. Exocytosis is preceded by PKA-dependent phosphorylation of proteins involved in the transport of insulin granules from the so-called reserve pool to the readily releasable pool [1]. Moreover, cAMP acts synergistically with glucose to reduce the activity of ATP-dependent $\mathrm{K}+$-channels [4], activate L-type $\mathrm{Ca}^{2+}$ channels [3], and accelerate the exocytotic process [2, 7]. Forskolin and the incretins, gastric inhibitory peptide (GIP) and glucagon-like peptide 1 (GLP-1), are known to amplify glucosestimulated insulin release by activating adenylate cyclase in the insulin cells [3]. Although many of the events listed above are thought to be mediated by PKA, recent data have suggested that cAMP enhances insulin secretion also through a PKA-independent pathway, involving cAMP-regulated guanine nucleotide exchange factor II (cAMP-GEFII or Epac) [8]. Stimulation of cAMP-GEFII impacts on $\mathrm{Ca}^{2+}$-induced mobilization of intracellular $\mathrm{Ca}^{2+}[6]$ and is thought to help make secretory granules release-competent [2]. The role of cAMP in the regulation of glucose-stimulated insulin secretion is not fully understood and experimental results are sometimes contradictory, probably because cAMP acts through several different pathways. In fact, there is evidence for a subcellular compartmentalization of cAMP and cAMP-induced actions [9-11].

Gastrectomy (GX), in patients as well as in animals, impairs the ability of the insulin cells to respond to a glucose challenge with appropriate insulin release [12-16]. This has been studied previously in GX mice and in isolated pancreatic islets from GX mice [14]. From these data, we have suggested that the impairment might reflect the loss of a gastric regulatory peptide that serves to enhance the insulin response to oral as well as circulating glucose [14]. In that study we could show that the impaired insulin response to glucose in GX mice was associated with an enhanced responsiveness to cholinergic agents and to agents stimulating cAMP formation [14]. 
In the present study we have extended our previous investigation [14] in order to further explore the nature of the GX-induced defects in the insulin secretory machinery, especially with regard to the cAMP system. To this end, we determined cAMP in freshly isolated islets and studied the insulin response to glucose and to the adenylate cyclase activator forskolin as well as the ability of the islets to accumulate cAMP upon incubation in the presence of different concentrations of glucose. In addition, we compared isolated insulin cells from GX mice and control mice with respect to the impact of cAMP on their electrophysiological properties.

\section{Materials and methods}

\subsection{Animals}

Twenty-eight female mice of the NMRI strain (B\& K Universal, Sollentuna, Sweden) were used in the experiments. They weighed $26.7 \mathrm{~g} \pm 0.7$ before the operation. They were kept on a standard pellet diet (Lactamin, Stockholm, Sweden) and tap water ad libitum. Before surgery, they were anaesthetized with mebumal (25 mg per mouse, i.p.). Surgery was performed through a midline abdominal incision with clean but not sterile instruments. No antibiotics were used. Gastrectomy (GX) was performed by resecting the stomach and anastomosing the oesophagus and the duodenum end-to-end. Sham operation consisted of an abdominal midline incision and manipulation of the viscera (laparatomy). The animals were allowed to recuperate for 4-6 weeks before they were subjected to experiments. During this time period suitable after-care was given to the animals to make sure that they suffered no pain or distress. One of the $15 \mathrm{GX}$ mice died (during the first few days after surgery). At the time of the experiment the GX mice weighed $30.9 \mathrm{~g} \pm 1.2(\mathrm{n}=14)$ and the sham-operated mice $32.3 \mathrm{~g} \pm$ $0.9(\mathrm{n}=13)$. The animal experiments were approved by the local animal welfare committee (Lund, Sweden).

\subsection{Chemicals}

Collagenase (fraction CLS 4) was obtained from Worthington Biochemicals, Freehold, NJ, USA. Bovine serum albumin was from ICN Biochemicals, High Wycombe, UK. Isobutylmethylxanthine (IBMX), an inhibitor of phosphodiesterase, and all other drugs and chemicals were from Sigma Chemicals, St Louis, MO, USA or Merck AG, Darmstadt, Germany. Radioimmunoassay kits for insulin determination were obtained from Diagnostika (Falkenberg, Sweden). 


\subsection{Experimental protocol}

Pancreatic islets. Pancreatic islets were isolated by retrograde injection of a collagenase solution via the bile-pancreatic duct [17]. Islets (of similar size) were then collected under a stereomicroscope at room temperature (usually 250 islets per mouse pancreas). In one experiment (shown in Fig. 1) $0.2 \mathrm{mmol} / 1$ IBMX was present during the isolation procedure in order to prevent the degradation of cAMP. The freshly isolated islets were either directly subjected to cAMP determination (see below) or preincubated for $30 \mathrm{~min}$ at $37^{\circ} \mathrm{C}$ in $\mathrm{Krebs}$ Ringer bicarbonate (KRB) buffer, pH7.4, supplemented with $10 \mathrm{mmol} / 1 \mathrm{~N}-2$ hydroxyethylpiperazine- $\mathrm{N}^{\prime}$-2-ethanesulfonic acid, $0.1 \%$ bovine serum albumin and $4 \mathrm{mmol} / \mathrm{l}$ glucose before adding the agents to be tested. Each incubation vial contained either 10 islets (insulin measurement) or 70 islets (cAMP measurement) in $1.5 \mathrm{ml}$ buffer solution and was gassed with $95 \% \mathrm{O}_{2}{ }^{-} 5 \% \mathrm{CO}_{2}$ to obtain constant $\mathrm{pH}$ and oxygenation. After preincubation, the medium was supplemented with $0.2 \mathrm{mmol} / 1 \mathrm{IBMX}$ and the different agents to be tested. The islets were incubated for $1 \mathrm{~h}$ at $37^{\circ} \mathrm{C}$ in a metabolic shaker ( 30 cycles per min) and aliquots of the medium was removed for the assay of insulin. The islets were then washed and collected for the measurement of cAMP.

\subsection{Measurement of insulin.}

Aliquots of the medium $(5-20 \mu \mathrm{l})$ were diluted to $100 \mu \mathrm{l}$ and insulin was determined by radioimmunoassay [14]. The results are presented as ng insulin released per islet during incubation for $1 \mathrm{~h}$.

\subsection{Measurement of cAMP.}

Determination of cAMP was performed essentially as described previously [18]. The islets were washed in glucose -free Krebs-Ringer buffer and placed in $500 \mu 1$ of ice-cold $10 \%$ trichloroacetic acid (TCA) containing the phosphodiesterase inhibitor IBMX (0.2 mmol/l), followed by immediate freezing in a $-70^{\circ} \mathrm{C}$ ethanol bath. Before assay, $500 \mu 1$ of $\mathrm{H}_{2} \mathrm{O}$ was added, and the samples were sonicated ( $3 \times 5$ seconds) followed by centrifugation $(1100 \mathrm{x} g)$ for 15 minutes. The supernatants were collected and extracted with water-saturated diethyl ether $(4 \times 2 \mathrm{ml})$. The aqueous phase was removed and freeze dried, using a Lyovac GT 2 freeze dryer. The residue was then dissolved in $450 \mu \mathrm{l}$ of Na-acetate buffer $(50 \mathrm{mmol} / \mathrm{l}, \mathrm{pH} 6.2)$. cAMP was measured with a ${ }^{125}$ I-cAMP radioimmunoassay kit (RIANEN, Du Pont, Boston, MA; USA). Known amount of $\left[{ }^{3} \mathrm{H}\right]$-cAMP was added to the homogenate in order to 
determine the recovery of cAMP during the extraction. The recovery was $90 \%$. The results are presented as fmol cyclic AMP per islet.

\subsection{Electrophysiology.}

Insulin cells were dispersed from the islets and prepared as described previously [2]. They were distinguished from glucagon cells by their characteristic electrophysiological properties $[19,20]$. The individual insulin cells were used to record whole-cell currents using an EPC-9 patch clamp amplifier and the software Pulse (Heka Electronics, Lamprecht/Pfalz, Germany). Membrane currents were filtered at $3.3 \mathrm{kHz}$ and digitised at $10 \mathrm{kHz}$. Exocytosis was detected as change in cell membrane capacitance $(\Delta \mathrm{Cm})$ using the lock-in function of the amplifier, which adds a $500 \mathrm{~Hz}$ sinus wave to the holding potential. Exocytosis was elicited by voltageclamp depolarisations. Patch electrodes were pulled from borosilicate capillaries, coated with Sylgard $₫$ and fire-polished. Each pipette was filled with the intracellular solution specified below. The resistance of the pipettes ranged between 3 and $6 \mathrm{M} \Omega$. Experiments were conducted using the standard whole cell configuration. The extracellular solution contained (in mmol/l): $118 \mathrm{NaCl}, 20$ tetraethyl-ammonium chloride (TEA) (to block voltage-gated $\mathrm{K}^{+}$ channels), 5.6 KCl, 2.6 $\mathrm{CaCl}_{2}, 1.2 \mathrm{MgCl}_{2}, 5$ glucose, 5 HEPES. The intracellular solution contained (in mmol/l): 125 Cs-glutamate, $10 \mathrm{CsCl}, 10 \mathrm{NaCl}, 1 \mathrm{MgCl}_{2}, 3 \mathrm{Mg}$-ATP, $50 \mu \mathrm{M}$ EGTA, 5 HEPES. $100 \mathrm{nmol} / 1 \mathrm{cAMP}$ was included in the pipette-solution as indicated in the text.

\subsection{Statistics}

Probability levels of random differences were determined by analysis of variance followed by Tukey-Kramer's multiple comparisons test or whenever applicable by Student's t-test. The results were expressed as means $\pm \mathrm{SEM}$.

\section{Results}

\section{1. cAMP content in islets isolated from $G X$ or control mice}

First we measured cAMP in freshly isolated pancreatic islets from GX and control mice. Figure 1 shows that the cAMP content in islets from GX mice was more than 2-fold higher than in islets from control mice (Fig 1A). This difference persisted when the islets were isolated in the presence of IBMX $(0.2 \mathrm{mmol} / \mathrm{l})$ (Fig. 1B). 


\subsection{Insulin secretion and cAMP accumulation in islets isolated from $G X$ or control mice}

\section{following incubation with forskolin or high glucose}

Pancreatic islets from GX mice, incubated in the presence of 4.0.mmol/1 glucose for $1 \mathrm{~h}$, released almost as much insulin as islets from control mice (Fig. 2A). At the end of the incubation they had a higher cAMP content $(50 \%, \mathrm{p}<0.01)$ than islets from control mice (Fig 2B), which is reminiscent of the difference seen in freshly isolated islet (Fig. 1). Addition of forskolin (a universal stimulator of cAMP formation) to the incubation medium induced a greater insulin response in islets from GX mice than in islets from control mice (Fig. 2A). Moreover, the cAMP content of islets from GX mice incubated in the presence of forskolin (Fig. 2B) and the corresponding net increase in the cAMP content (Fig. 3) were higher than in islets from control mice. When stimulated by high glucose $(16.7 \mathrm{mmol} / \mathrm{l})$, the insulin response was much weaker in islets from GX mice than from control mice (Fig. 2A). The attenuated insulin response of the GX islets to high glucose was accompanied by a failure of glucose to stimulate cAMP production (Fig. 2B), particularly evident when calculating the glucoseevoked cAMP increase (Fig 3) above the level found in freshly isolated islets (Fig. 1A). A similar difference was obtained when using the results shown in Fig. 1B as starting levels (data not shown).

\subsection{Electrophysiological characteristics of individual insulin cells prepared from islets of}

\section{GX or control mice}

The exocytotic process was examined by capacitance measurements on individual insulin cells. Insulin cells from GX mice were compared with insulin cells from control mice. A 500 $\mathrm{ms}$ depolarisation from $-70 \mathrm{mV}$ to zero increased the capacitance (exocytosis) of insulin cells (expressed as $\Delta \mathrm{Cm}$ ) from control mice by $23 \pm 7$ femtoFarad (fF) (n=13; Fig 4A, C).

Exocytosis was enhanced in the presence of $100 \mu \mathrm{M}$ cAMP in the pipette solution, the capacitance increase amounting to $96 \pm 38 \mathrm{fF}(\mathrm{n}=6)$. By comparison, the exocytotic response was much lower in insulin cells from GX mice and the addition of cAMP to the pipette solution did not enhance it. The capacitance increase was $7 \pm 3 \mathrm{fF}(\mathrm{n}=23)$ in the absence and $11 \pm 2 \mathrm{fF}(\mathrm{n}=18)$ in the presence of cAMP (Fig. 4B). The results are summarized in Fig. 4C.

To explore the possibility that the impaired exocytotic response observed in insulin cells from GX mice reflected an impaired exocytosis-triggering inward $\mathrm{Ca}^{2+}$ current, the inward current evoked by depolarising pulses was varied from $-70 \mathrm{mV}$ to $+40 \mathrm{mV}$. In insulin cells from control mice (no cAMP added) the current peaked at $0 \mathrm{mV}$ (Fig. 4D) and amounted to $36 \pm 4$ 
pA (picoAmpere) $(n=8)$. The measured peak-current was plotted against the voltage and approximated by a modified Boltzman equation (Eq.1).

$$
I_{p}=G \times \frac{\left(V_{m}-V_{r}\right)}{1-e^{\frac{\left(V_{m}-V_{h}\right)}{k}}}
$$

$I_{p}$ is the measured peak-current, $G$ is the whole-cell conductance, $V_{m}$ is the voltage of the depolarizing pulse, $\mathrm{V}_{\mathrm{r}}$ is the extrapolated reversal potential, $\mathrm{V}_{\mathrm{h}}$ is the membrane potential at which the current is half-maximal and $\mathrm{k}$ is the slope coefficient. Approximating the data measured in the abscence of cAMP on insulin cells from control mice to Eq. 1 gave the values of $\mathrm{G}, \mathrm{V}_{\mathrm{r}}, \mathrm{V}_{\mathrm{h}}$ and $\mathrm{k}$ of $0.7 \pm 0.2 \mathrm{nS}$ (nanoSiemens), $72 \pm 8 \mathrm{mV},-13 \pm 8 \mathrm{mV}$ and $18 \pm 4 \mathrm{mV}$, respectively. These values were not significantly different when the same experiments were performed on insulin cells from GX mice (Fig. 4D), not even in the presence of $0.1 \mathrm{mmol} / 1$ cAMP (Fig. 4E). Thus, the inward $\mathrm{Ca}^{2+}$ current was not affected by $\mathrm{GX}$ and the reduced exocytotic response in insulin cells from GX mice can therefore not be explained by a decreased influx of $\mathrm{Ca}^{2+}$.

Further, we investigated how continued depolarisation-evoked stimulation affected the insulin cells. In contrast to the absence of an effect of cAMP on the stimulation evoked by a single depolarisation in insulin cells from GX mice (see Fig. 4C) we found that introducing cAMP into the pipette solution stimulated the exocytotic response to a train of ten $500 \mathrm{~ms}-$ depolarisations from -70 to $0 \mathrm{mV}$ (Fig. 5A). In insulin cells from control mice the total increase in capacitance amounted to $76 \pm 13 \mathrm{fF}(\mathrm{n}=13)$ and $186 \pm 64 \mathrm{fF}(\mathrm{n}=4)(\mathrm{p}<0.01)$, in the absence and presence of cAMP, respectively (Fig. 5B). In insulin cells from GX mice the depolarisation-induced capacitance remained unaffected by cAMP at first (Fig.5A); the total capacitance increase during the train was modestly enhanced by cAMP from $28 \pm 8 \mathrm{fF}$ to 63 $\pm 18 \mathrm{fF}(\mathrm{p}<0.05)($ Fig. 5B).

\section{Discussion}

In an earlier study [14], we combined in vivo and in vitro methods to investigate the insulin response to various secretagogues in GX mice. In line with earlier findings in patients who have undergone gastric surgery $[12,13,15,16]$, we found that GX mice displayed an impaired glucose tolerance associated with a markedly reduced insulin response to both oral and i.v. glucose loading [14]. Also the insulin response to glucose was much lower in islets 
isolated from GX mice than in islets from control mice. Surprisingly, there was no hyperglycaemia (and no hypoinsulinaemia) in freely fed GX mice. Conceivably, compensatory insulin-releasing mechanisms kick in to prevent the development of a disturbed carbohydrate metabolism in the GX mice (see [14]). Such a hypothesis received support from the observation that the insulin response to stimulators of the formation and mobilization of cAMP, such as the adenylate cyclase activator forskolin and the phosphodiesterase inhibitor IBMX, was greatly enhanced in the GX mice both in vivo and in vitro [14].

In the present investigation we extended our studies on the cAMP system in islets of GX mice. First, the results revealed much more cAMP in freshly isolated islets from GX mice (46 weeks after surgery) than in islets from control mice. The high cAMP content was most likely due to accelerated cAMP synthesis rather than to decreased phosphodiesterase activity, since the difference in islet cAMP content between GX and control mice remained after isolating the islets in the presence of the phosphodiesterase inhibitor IBMX. Second, we found that the cAMP content in islets from GX mice remained higher than in control islets after incubation at a non-stimulatory concentration of glucose $(4 \mathrm{mmol} / \mathrm{l})$ and that the cAMP content was greatly increased (more than in control islets) after addition of forskolin to the incubation medium. The forskolin-induced rise in cAMP was accompanied by enhanced insulin release. These results are in accord with earlier observations [14], showing that GX mice display a much greater insulin response to cAMP-activating secretagogues than do control mice. In contrast, as mentioned above, the glucose-stimulated insulin response in GX mice was much reduced compared with controls [14]. This is in accord with the results of the present study, showing that high glucose $(16.7 \mathrm{mmol} / \mathrm{l})$ did not raise cAMP in islets from GX mice, while a 2-fold increase was observed in control islets. High glucose induced an almost 6-fold increase of insulin release from islets of control mice and a mere 3-fold increase in islets from GX mice, suggesting that approximately $50 \%$ of the glucose-stimulated insulin release from control islets is somehow dependent upon cAMP and that glucose-stimulated insulin release from islets of GX mice, at least in part, is impaired because the cAMP levels in these islets do not respond properly to glucose stimulation. Hence, the ability of glucose to raise islet cAMP seems to depend on factor(s) originating from the stomach, although it cannot be excluded that the impairment of insulin secretion might reflect instead severed neural connections between the stomach and the pancreas. We have previously presented evidence that an agent, possibly a peptide, residing in the oxyntic mucosa, amplifies glucosestimulated insulin release from islets of GX mice [14]. Conceivably, the same factor is 
required to enable glucose to raise islet cAMP, making the insulin cells capable of releasing the appropriate amount of insulin in response to a glucose stimulus. Interestingly, in the in vivo situation, intestinal incretins, such as GIP or GLP-1, are thought to act in the same way [21]. Conceivably, in the insulin cells, different cAMP compartments [11] are drawn upon to ensure an optimal insulin response to glucose. Similarly, glucose itself might stimulate the formation of cAMP in a specific compartment in insulin cells of control mice. In GX mice this particular glucose-sensitive cAMP compartment is down-regulated. However, other agents, neurotransmitters or circulating hormones, may compensate for the down-regulation of this particular glucose-sensitive cAMP compartment by exaggerating non-glucosestimulated insulin release [14]. Such a scenario would place the hypothetical gastric insulinotropic factor in the role of mobilizer of cAMP from a specific and sequestered glucose-sensitive cAMP compartment, needed to attain the appropriate insulin response to glucose.

The electrophysiological experiments revealed a much lower exocytotic response to a $500 \mathrm{~ms}$ depolarisation in isolated insulin cells from GX mice than from control mice, bringing to mind the poor insulin response to glucose in islets from GX mice. The addition of cAMP to the pipette solution failed to enhance the impaired exocytotic response to depolarisation in insulin cells from GX mice, while the response of insulin cells from control mice was greatly increased . The exocytosis-triggering inward $\mathrm{Ca}^{2+}$ current was the same in insulin cells from control and GX mice and hence cannot explain the poor exocytotic response in the latter cells. Although a prolonged depolarisation series (a train of ten depolarisations) in the presence of cAMP induced a modest enhancement of the exocytotic response in insulin cells from GX mice, the magnitude of the response was still far from that observed in insulin cells from control mice. Hence, the effects of depolarisation were again reminiscent of the effects of glucose on islets from GX mice where the insulin response was poor and the cAMP content did not increase. The modest amplifying effect of cAMP on the exocytotic response was of insulin cells from GX mice exerted mainly on the latter part of the train, cAMP having little or no effect on the first depolarisations in the series (Fig. 5A). According to the results of earlier experiments on insulin cells from control mice [2,7], cAMP stimulates depolarizationevoked exocytosis via both a PKA-dependent[2, 14] and a PKA-independent pathway [6, 8]. The PKA-dependent pathway is involved in the transport of insulin granules to the plasma membrane, while the PKA-independent pathway involves the cAMP-binding protein cAMPGEFII and leads to stimulated insulin secretion by an action at the release site [2]. Stimulation 
of this latter pathway can be observed through capacitance measurement (conducted on individual cells) during the first hundred milliseconds of a depolarisation from $-70 \mathrm{mV}$ to 0 , i.e. during the first depolarisations of the train. Hence, the impaired depolarisation response in insulin cells from GX mice suggests an impaired PKA-independent pathway. A reason for the defective glucose-stimulated insulin release and poor exocytotic response to depolarisation in GX insulin cells might be the lack of a gastric factor needed for the smooth transduction of signals through a glucose-sensitive cAMP compartment related to the PKA-independent pathway.

In an earlier report it was suggested that the hypothetical insulinotropic agent in the stomach was a peptide [14], and that one of the majority populations of peptide hormone-producing endocrine cells in the acid-producing part of the rat stomach, i.e. the ECL cells [22] and the ghrelin cells [23], represented possible sources of this agent. Because ghrelin was recently found to inhibit rather than stimulate glucose-evoked insulin release [24, 25], an effect which at least in part was exerted by accelerating islet NO production [25], ghrelin is unlikely to be the insulinotropic agent. However, an insulinotropic agent may originate in any one of the different gastric endocrine cells.

\subsection{Concluding remarks}

The present data lend support to our earlier proposal that a gastro-insular axis is important for effective insulin release in response to glucose [14]. We now report that the greatly impaired insulin response to glucose in islets from GX mice is associated with a markedly reduced exocytotic response as revealed by capacitance measurements. Islets from GX mice had elevated cAMP content and responded with exaggerated insulin release to the universal adenylate cyclase activator forskolin. However, high glucose raised the cAMP level in islets from control mice, but not in islets from GX mice. Conceivably, a gastric agent is needed to mobilize cAMP from a specific, glucose-sensitive compartment in order to generate an appropriate insulin response to glucose.

\section{Acknowledgements}

This study was supported by grants from the Swedish Research Council (K2006-04X), NOVO Nordic, Albert Påhlsson, and Crafoord Foundations. The technical assistance of BrittMarie Nilsson is gratefully acknowledged. 


\section{REFERENCES}

[1]. Rorsman P, Renström E. Insulin granule dynamics in pancreatic beta cells. Diabetologia 2003; 46: 1029-45.

[2]. Eliasson L, Ma X, Renström E, Barg S, Berggren PO, Galvanovskis J, Gromada J, Jing X, Lundquist I, Salehi A, Sewing S, Rorsman P. SUR1 regulates PKAindependent cAMP-induced granule priming in mouse pancreatic B-cells. J Gen Physiol 2003; 121: 181-97.

[3]. Ämmälä C, Ashcroft FM, Rorsman P. Calcium-independent potentiation of insulin release by cyclic AMP in single beta-cells. Nature 1993; 363: 356-8.

[4]. Holz GGT, Kuhtreiber WM, Habener JF. Pancreatic beta-cells are rendered glucosecompetent by the insulinotropic hormone glucagon-like peptide-1(7-37). Nature 1993; 361: 362-5.

[5]. Dyachok O, Gylfe E. Ca(2+)-induced $\mathrm{Ca}(2+)$ release via inositol 1,4,5-trisphosphate receptors is amplified by protein kinase $\mathrm{A}$ and triggers exocytosis in pancreatic betacells. J Biol Chem 2004; 279: 45455-61.

[6]. Kang G, Chepurny OG, Holz GGT. cAMP-regulated guanine nucleotide exchange factor II (Epac2) mediates $\mathrm{Ca} 2+$-induced $\mathrm{Ca} 2+$ release in INS-1 pancreatic beta-cells. J Physiol 2001; 536: 375-85.

[7]. Renström E, Eliasson L, Rorsman P. Protein kinase A-dependent and -independent stimulation of exocytosis by cAMP in mouse pancreatic B-cells. J Physiol 1997; 502: 105-18.

[8]. Ozaki N, Shibasaki T, Kashima Y, Miki T, Takahashi K, Ueno H, Sunaga Y, Yano H, Matsuura Y, Iwanaga T, Takai Y, Seino S. cAMP-GEFII is a direct target of cAMP in regulated exocytosis. Nat Cell Biol 2000; 2: 805-11.

[9]. Steinberg SF, Brunton LL. Compartmentation of $G$ protein-coupled signaling pathways in cardiac myocytes. Annu Rev Pharmacol Toxicol 2001; 41: 751-73.

[10]. Tasken K, Aandahl EM. Localized effects of cAMP mediated by distinct routes of protein kinase A. Physiol Rev 2004; 84: 137-67.

[11]. DiPilato LM, Cheng X, Zhang J. Fluorescent indicators of cAMP and Epac activation reveal differential dynamics of cAMP signaling within discrete subcellular compartments. Proc Natl Acad Sci U S A 2004; 101: 16513-8.

[12]. Muir A. Postgastrectomy syndrome. Br J Surg 1949; 37: 165-78.

[13]. Tobe T, Kouchi M, Tanimura H, Huang CH. Hyperglycemia after gastrectomy as a prediabetic state. Clinical study of 100 postgastrectomy patients. Arch Surg 1967; 94: 836-40.

[14]. Salehi A, Chen D, Håkanson R, Nordin G, Lundquist I. Gastrectomy induces impaired insulin and glucagon secretion: evidence for a gastro-insular axis in mice. J Physiol 1999; 514: 579-91.

[15]. Breuer RI, Moses H, 3rd, Hagen TC, Zuckerman L. Gastric operations and glucose homeostasis. Gastroenterology 1972; 62: 1109-19.

[16]. Sudo T, Ishiyama K, Takemoto M, Kawamura M, Umemura H, Shiraha S, Kuyama T, Suzuki T, Tobe T. Pancreatic endocrine function after total gastrectomy and truncal vagotomy. Am J Surg 1982; 144: 539-44.

[17]. Gotoh M, Maki T, Kiyoizumi T, Satomi S, Monaco AP. An improved method for isolation of mouse pancreatic islets. Transplantation 1985; 40: 437-8.

[18]. Salehi A, Ekelund M, Lundquist I. Total parenteral nutrition-stimulated activity of inducible nitric oxide synthase in rat pancreatic islets is suppressed by glucagon-like peptide-1. Horm Metab Res 2003; 35: 48-54. 
[19]. Barg S, Galvanovskis J, Göpel SO, Rorsman P, Eliasson L. Tight coupling between electrical activity and exocytosis in mouse glucagon-secreting alpha-cells. Diabetes 2000; 49: 1500-10.

[20]. Göpel S, Zhang Q, Eliasson L, Ma XS, Galvanovskis J, Kanno T, Salehi A, Rorsman P. Capacitance measurements of exocytosis in mouse pancreatic \{alpha\}-, \{beta $\}$ - and \{delta\}-cells studied in intact islets of Langerhans. J Physiol 2004; 556: 711-726.

[21]. Hansotia T, Drucker DJ. GIP and GLP-1 as incretin hormones: lessons from single and double incretin receptor knockout mice. Regul Pept 2005; 128: 125-34.

[22]. Sundler F, Håkanson R. (1988) Peptide hormone-producing endocrine/paracrine cells in the gastro-entero-pancreatic region. In: Handbook of Chemical Neuroanatomy. Vol. 6 (eds. A Björklund, T Hökfelt, C Owman), pp 219-295. Elsevier, Amsterdam.

[23]. Dornonville de la Cour C, Björkqvist M, Sandvik AK, Bakke I, Zhao CM, Chen D, Håkanson R. A-like cells in the rat stomach contain ghrelin and do not operate under gastrin control. Regul Pept 2001; 99: 141-50.

[24]. Salehi A, Dornonville De La Cour C, Håkanson R, Lundquist I. Effects of ghrelin on insulin and glucagon secretion: a study of isolated pancreatic islets and intact mice. Regul Pept 2004; 118: 143-50.

[25]. Qader SS, Lundquist I, Ekelund M, Håkanson R, Salehi A. Ghrelin activates neuronal constitutive nitric oxide synthase in pancreatic islet cells while inhibiting insulin release and stimulating glucagon release. Regul Pept 2005; 128: 51-6. 


\section{Legends to Figures}

Figure 1. cAMP content in islets from sham-operated (control) and gastrectomized (GX) mice isolated "ex vivo" in the absence (A) and presence (B) of $0.2 \mathrm{mmol} / 1 \mathrm{IBMX}$. Means \pm SEM for four batches of islets; each batch isolated from one mouse. Significant difference between GX and controls $* * p<0.01 ; * * p<0.001$.

Figure 2. (A) Insulin release and (B) islet cAMP accumulation in islets isolated from shamoperated (control) or gastrectomized (GX) mice and incubated for $1 \mathrm{~h}$ in the presence of 0.2 $\mathrm{mmol} / \mathrm{l} \mathrm{IBMX}$. Accumulated cAMP levels at $4 \mathrm{mmol} / \mathrm{l}$ glucose $(4 \mathrm{G})$ as well as the effects of $4 \mathrm{G}+20 \mu \mathrm{mol} / 1$ forskolin (forsk) or $16.7 \mathrm{mmol} / 1$ glucose $(16.7 \mathrm{G})$ are shown. Means $\pm \mathrm{SEM}$ for four batches of islets; each batch isolated from one mouse. Significant difference between GX mice and control mice are denoted by asterisks $(*) * * p<0.01, * * * p<0.001$. Stars $(\star)$ are indicated for differences between controls incubated in 4 vs $16.7 \mathrm{mmol} / 1$ glucose, $\mathrm{p}<0.001 ; \mathrm{ns}=$ not significant.

Figure 3. Difference $(\Delta)$ in cAMP content between freshly isolated islets (shown in Fig. 1A) and islets incubated for $1 \mathrm{~h}$ in the presence of $0.2 \mathrm{mmol} / 1 \mathrm{IBMX}$ (shown in Fig. 2B). Means \pm SEM $(n=4)$. Significant difference between GX mice and control mice are denoted by asterisks $(*) * * \mathrm{p}<0.01, * * * \mathrm{p}<0.001$. Stars $(\star)$ indicate differences in cyclic AMP content between control islets incubated in 4 vs $16.7 \mathrm{mmol} / 1$ glucose, $\star \star \star \mathrm{p}<0.001$

\section{Figure 4.}

$\mathrm{Ca}^{2+}$-dependent exocytosis in sham-operated (control) and gastrectomized (GX) mice. (A) Typical recording of current (expressed as $\mathrm{pA}$ ) and capacitance change (expressed as $\mathrm{fF}$ ) in response to voltage clamp depolarisation from -70 to zero $\mathrm{mV}$ applied to a single insulin cell from a control mouse in the absence (left) and presence (right) of cAMP. (B) The same protocol as in (A) applied to a single insulin cell from a GX mouse, revealing a greatly impaired response to depolarisation. (C) Increase in membrane capacitance $(\Delta \mathrm{Cm})$ in (A) and (B). The data are presented as mean values \pm SEM of 6-23 experiments on insulin cells from 4 GX mice, and 6 control mice. (D) Peak current $\left(\mathrm{I}_{\mathrm{p}}\right)$-voltage $(\mathrm{V})$ relationship for the inward Ca ${ }^{2+}$-current in insulin cells from control mice $(\circ)$ and GX mice $(\bullet)$. (E) Same as in D for insulin cells from GX mice in the absence ( $\square$ ) and presence of cAMP ( $\square$ ). The data in (D) and (E) 
were approximated to Eq. 1 and presented as mean values \pm SEM of 8-13 experiments on insulin cells from 4 GX mice and 6 control mice. $* * \mathrm{P}<0.01$

\section{Figure 5.}

Electrical stimulation of individual insulin cells from gastrectomized (GX) mice. Increase in membrane capacitance $(\Delta \mathrm{Cm})$ was recorded. (A) Trains of ten 500-ms depolarising pulses were applied in the presence and absence of cAMP. Identical experiments were conducted on insulin cells from sham-operated (control) mice (not shown). (B) Histogram summarizing the total increase in membrane capacitance from experiments in (A), revealing a greatly impaired response to depolarisation in insulin cells from GX mice. The data are presented as mean values \pm SEM from 4-20 experiments on insulin cells from 4 GX mice. ${ }^{*} \mathrm{P}<0,05,{ }^{*} * \mathrm{P}<0,01$. 


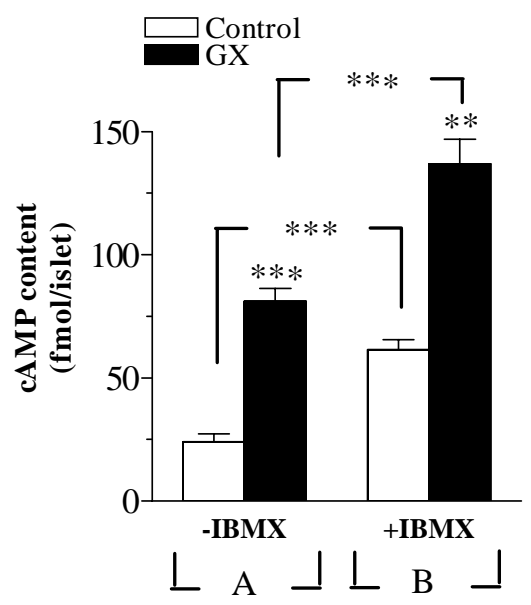

Fig. 1 
GX-IRI-1,2.pzm:Layout-1 - Tue Jan 17 16:20:39 2006

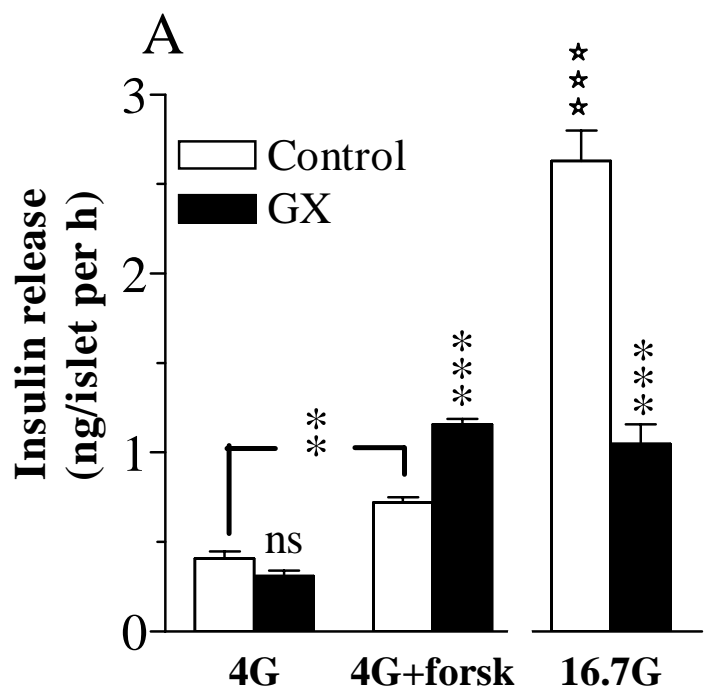

B

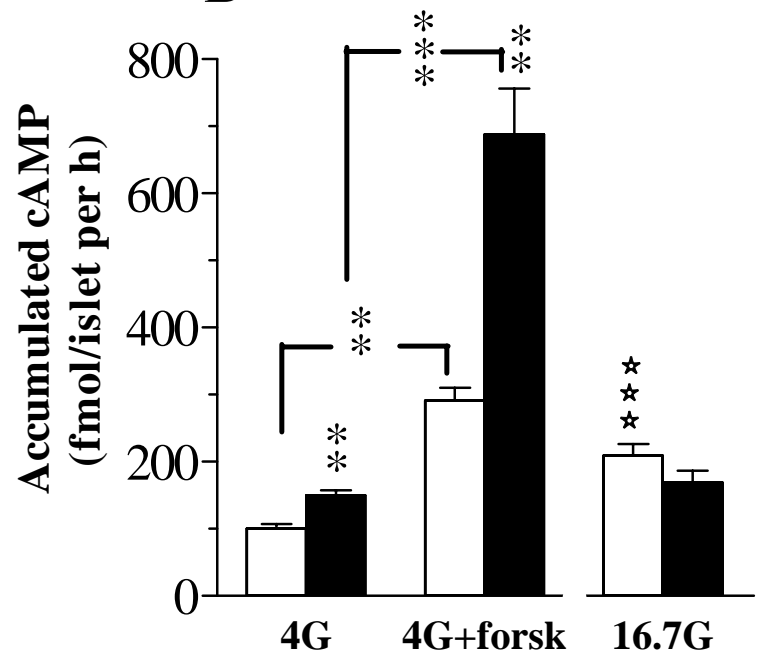

Fig. 2 




Fig. 3 
Fig. 4

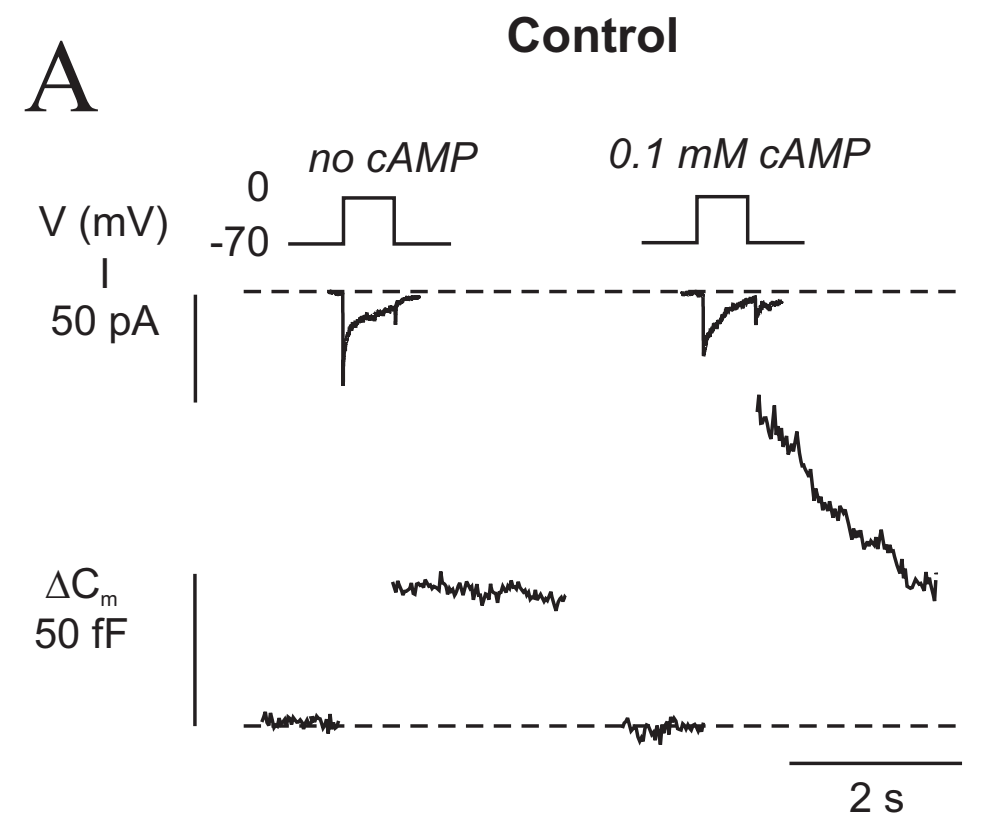

B

Gx


D

E

Gx

Fig. 5


Control Gx

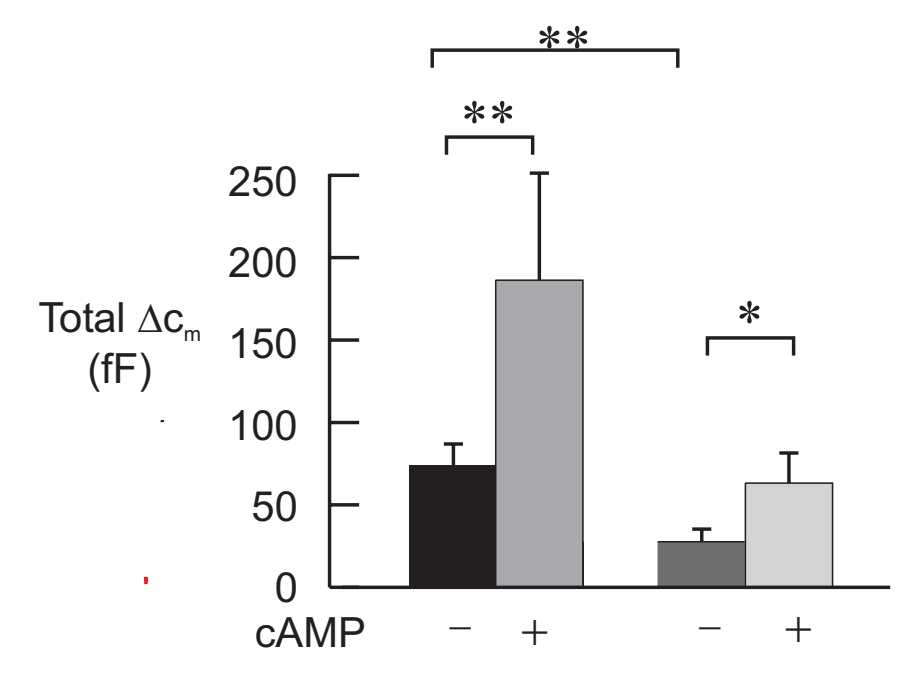

